\title{
Whose Life is it Anyway? Exploring the Social Relations of High-Conflict Divorce Cases in Southern Norway
}

\author{
Bård Bertelsen ${ }^{1,2,3}$ \\ Accepted: 10 March 2021 / Published online: 20 March 2021 \\ (c) The Author(s) 2021
}

\begin{abstract}
The paper reports on findings from an empirical study based on qualitative interviews with Norwegian parents identified as part of a high-conflict divorce situation and interviews with caseworkers from a child welfare service. The site of study is an institutional circuit of concern, assessment, and referral involving the court, child welfare services, and a public family therapy service. The paper draws on the social ontology and analytic concepts of institutional ethnography and adopts parents' standpoint to explore how their knowledge and experience are shaped through encounters with professionals in the process of being identified and assessed as a high-conflict divorce case. The focus on people's doings and their expert knowledge about their doings sets institutional ethnographic research apart from more conventional forms of qualitative inquiry that focus on informants' inner experience. The paper highlights how a generalized professional discourse seems to permeate the work that parents and caseworkers jointly engage in, sometimes subsuming the knowledge and experience of those involved. When the issues of life as subjectively known and experienced are different from those of the institutional discourse, there is a danger that what is important to those whose lives they concern escapes the dialogue between parents and professionals.
\end{abstract}

Keywords Experience $\cdot$ High-conflict divorce $\cdot$ Institutional ethnography $\cdot$ Institutional circuit $\cdot$ Parents

\section{Introduction}

Father: "One of my goals, since the second court.... second child welfare... first child welfare case, and first... second court proceeding... first court proceeding, has been for my daughter not to be institutionalized, repeatedly having to expose herself and her family in treatment, in assessment interviews, and all that, the whole bloody time. Because it has been a lot." Interviewer: "It sounds almost like a lifestyle?" Father: "Yes, growing up somewhere between a psychologist and the child welfare service. When she should just have been outside, playing."

Bård Bertelsen

bard.bertelsen@gmail.com

1 The Family Counseling Office in Arendal, Arendal, Norway

2 Department of Child and Youth Mental Health Arendal, South Norway Hospital, Arendal, Norway

3 Department of Psychosocial Health, Faculty of Health and Sports Sciences, University of Agder, Grimstad, Norway
This piece of dialogue comes from a research interview with a father, conducted a few days before he was to start participating in a multi-family group therapy program for parents and children living with high levels of conflict between parents after divorce. It shows a disjuncture between his local, parental desire to provide his daughter with a 'normal' childhood and how he had come to publicly enact his fatherhood by engaging with professionals in court proceedings, child welfare assessments, and other institutional services. This points to a key finding in the present paper, which is part of a study based on qualitative interviews with Norwegian parents identified as part of a high-conflict divorce situation. Their individual trajectories towards becoming high-conflict divorce cases involved repeated encounters with welfare and other public services. For some, this resulted in a process of alienation where they experienced a detachment from values subjectively held as central to their parenthood. For others, it provided opportunities to develop and grow as parents. Irrespective of the consequences in each particular instance, their stories collectively illuminate a side of high-conflict divorce that is less debated in the family therapy literature than is the search for effective clinical interventions and public policies. This 
has to do with how the social relations of governance and bureaucracy not only provide guidelines and venues for helpful exchanges between parents, children, and professionals; they also afford directions and limits for understanding, thus orchestrating people's lives in specific, objectified ways. This paper aims to provide an empirical exploration of how this sometimes comes to happen.

\section{Separation and Divorce in the Norwegian Context}

In Norway, between 30 and 40 percent of all children presently experience family break-up or have never lived together with both parents (Statistics Norway, 2020). Beginning in the 1990s, the number of disputes about child-related issues that ended up in court rose considerably in Norway (Koch 2008; Vimblemo, Tobra, Knutsen, Olsen, Gleinsvik \& Bush 2016), as it did in many other Western countries (Bergman \& Rejmer, 2017; Parkinson, 2011). For separating and divorcing families, a standard estimate is that between ten and 15 percent will end up in a pattern of entrenched conflict between parents (Haddad, Philips \& Bone 2016; Helland \& Borren, 2015; Hetherington, 2002; Mahrer et al. 2018; Wiik, Kitterød, Lyngstad \& Lidén 2015). The concept of 'high-conflict divorce' refers to situations where parents remain in patterns of interaction characterized by long-lasting and bitter disputes over child-related concerns for several years after separation (Anderson et al. 2010; Birnbaum \& Bala, 2010). Research has consistently demonstrated that such prolonged conflicts between parents after divorce can be detrimental for children's well-being and psychosocial health (Amato, 2000; Amato \& Keith, 1991; DeBoard-Lucas et al. 2010; Emery, 1999; Fincham et al. 1994; Grych, 2005; Lansford, 2009; Visser et al. 2017).

In Norway, mediation is mandatory for separating parents with children below the age of 16, whether they are married (Marriage Act, 1991, § 26) or cohabiting (Children Act, $1981, \S 51$, third paragraph). Mediation is also mandatory for parents seeking court litigation over issues concerning the care of their children after divorce or breakup (Children Act, 1981, § 51, first paragraph). The Norwegian mediation scheme's main intention is to promote cooperation through assisting parents in reaching an agreement regarding future care for their children (Barne- og familiedepartementet, 2006).

In this context, mandatory mediation facilitates direct governmental involvement in all instances of parental breakup involving children. This situates the family counseling offices responsible for mediation as part of an institutional complex that further involves the courts and sometimes the child welfare services. Mediators' main task is to function as consultants for parents towards preparing a written agreement concerning the future joint care for their children (Barne- og familiedepartementet, 2006). If parents cannot agree on a joint parenting scheme during mediation, they can seek court litigation. The court's judicial authority allows for direct regulation of the domestic sphere (Ottosen, 2006). When the court accepts a parental dispute for litigation, the judge must decide whether a settlement is likely to be within reach, in which case a court mediation process is initiated. If not, or if court mediation is first attempted but proves unfruitful, a main hearing is held where the judge ultimately makes a judicial ruling (Children Act, 1981, chapter III; Domstoladministrasjonen, 2019). If parents repeatedly engage with these institutions without seeming to accomplish a de-escalation of conflict, child welfare services are sometimes notified. This is because prolonged conflict is itself considered a reason for concern for the well-being of children.

In 2013, the Norwegian government issued a guideline clarifying the child welfare services' responsibility in cases of concern for ongoing inter-parental custody disputes (Barne-, likestillings- og inkluderingsdepartementet 2013). In such cases, caseworkers must investigate the child's situation in both homes and offer voluntary supportive measures to one or both parents if deemed necessary. The guideline states that while caseworkers cannot directly intervene to alter any functioning custody or visitation agreement between parents (regulated in the Children Act, 1981), they may still advise parents on these same issues. Although rarely implemented, in extreme cases when parents are involved in a severe and prolonged conflict this can be considered a failure to meet the child's needs and may provide sufficient grounds for promoting a care order (regulated in the Child Welfare Act 1992). Thus, while child welfare services cannot dictate which solution parents should opt for in resolving custody disputes, the fact that conflict between parents is regarded as potentially harmful to children mandates caseworkers to demand that parents do something.

\section{High-Conflict Divorce as a Problematic for Research}

From a sociological perspective, Ottosen (2006) argues that both counseling, mediation, court proceedings, and child welfare procedures can be understood as expressions of the welfare state's aversion to interpersonal conflict and the state's power to discipline parents into cooperation. Although families found to be entrenched in conflict after a divorce are frequently referred to therapy by the judicial system in the hope of reducing conflict and avoiding new court filings (Anderson, Sumner, Parady, Whiting \& Tambling 2019), Johnston et al. (2009) argue that the rhetoric of lawyers, child welfare caseworkers, and other professionals often provide nourishment to parents' conflicts.

This paradox, between the expressed intentions behind policy and intervention strategies and the claim that the same policies and interventions sometimes contribute to 
produce or conserve the very phenomena they were made to prevent, marks the point of departure for the present paper. Drawing on data from a qualitative study consisting of interviews with parents and child welfare caseworkers, its goal is not to test or develop a set of theoretical assumptions about parenthood and high-conflict divorce. Nor is it to produce a phenomenological or thematic understanding of the psychological or inter-subjective aspects of a highconflict divorce situation. Instead, the paper aims to provide an empirical exploration of how parents' knowledge and experience get shaped through encounters with the institutions of the state, and how this is connected to the way postdivorce parenthood is socially organized through Norwegian policy and professional guidelines. Focusing specifically on encounters between parents and child welfare caseworkers leading up to a further referral to a family therapy intervention, the paper seeks to map one segment of the institutional sequence through which parents encounter the institutions of the welfare state because of concern for ongoing conflict. The research question guiding the paper is: how are parents' knowledge and experience shaped through encounters with caseworkers in the process of becoming a high-confict case? To this end, the paper draws on the sociological research strategy known as institutional ethnography (Smith, 1987, 1990a, 1990b, 1999, 2005).

\section{Institutional Ethnography}

As outlined by Smith (2005), institutional ethnography (IE) is a theorized empirical approach developed to explore the social relations that organize institutions as people participate in them, from their own perspectives. IE begins in the actualities of people's everyday activities, with a focus on how they participate in institutional relations. Treating people as expert knowers of their own lives, "it explores with people their experience of what is happening to them and their doings and how these are hooked up with what is beyond their experience" (Smith, 2005, p. 41). IE aims to generate knowledge about the ways in which taken-forgranted forms of governance work to rule everyday life. To do this, researchers must assemble what they learn from different perspectives and explore what connects them.

Compared to qualitative research approaches geared towards generating abstract theoretical explanations, institutional ethnography requires both an ontological and an epistemological shift (G. W. 1990b; Smith, 1990a, 2005, 2006). The ontological shift involves keeping analysis embedded in the everyday worlds of people's actual practices and activities. Hence, inquiry begins in an embodied standpoint, rather than in abject theory, and remains connected to this standpoint when tracing how peoples' activities and doings are socially organized and coordinated. Epistemologically, IE strives for ways of knowing that are experiential, from the inside, not for objective or ideological truths (Hussey, 2012; Kearney et al. 2019). Taken together, this positions institutional ethnography as a non-positivist approach; it does not seek to uncover reality as it 'really' is, and it avoids the kinds of causal logic that often lead to decontextualized analyses. Instead, IE invites reflexive ways of knowing that relate to a common world shared by researchers and research participants (Kearney et al. 2018).

IE's social ontology assumes that one person's activity "necessarily implies the presence and doings of others caught up in and participating in relations" that coordinate what is happening (Smith, 2005, p. 43). The term ruling relations (Smith, 1987, 2005) articulates how this coordination works to orchestrate the social relations of institutions. In modern societies, texts are principal instruments of ruling. Through policy documents, guidelines, forms, standard letters, computer fields, etc., social relations get replicated and circulated trans-locally, that is, across time and place (Rankin, 2017; Smith, 1990a, 1990b). At the local sites of people's experience, these texts appear as material artifacts. Engaging in what Smith (1990a, 1990b, 2005) refers to as text-reader conversations, people's use of texts gives ruling relations a material form. As they enter into and coordinate people's doings (as, for instance, when otherwise unrelated parents independently work out their parenting plans using the same template downloaded from the same government website), this materiality makes the ruling relations accessible as empirical data. It enables us to see them as embedded in social relations. Relying on these material forms of social organization, IE offers insights into the everyday work of ruling by tracking institutional sites that govern people's practices in local settings (Rankin, 2017). When organized around a specific function, different relational modes of ruling - like state authority, professional guidelines, and professional discourse-intersect to constitute the relational complexes referred to as institutions (Griffith \& Smith, 2014; Smith, 2005, 2006).

One of the things that distinguish IE from other critical modes of inquiry is its ability to explicitly discuss the situation on the front-line between service providers and service users and how this relates to outside organizing forces (Kearney et al., 2019). Griffith and Smith (2014) use the term institutional circuit to refer to sequences of institutional action where texts are produced by selectively choosing from actualities to build an account that accords with an authoritative or 'boss' text (like law, policy, or the frames of a particular discourse) in such a way that an institutional course of action can follow. Institutional circuits are not assumed to be objects to study. It is an analytical concept providing "a method of looking for how people coordinate what they do with one another" (Griffith \& Smith, 2014, p. 12). Within the institutional complex surrounding family policy and family therapy services, institutional hierarchies and regulations 
abound. This makes the field well suited for institutional ethnographic investigation.

\section{Methods}

\section{Participants and Recruitment}

\section{Parents}

Nineteen parents, representing a total of 11 co-parenting pairs, ${ }^{1}$ were interviewed. ${ }^{2}$ They consisted of nine mothers and ten fathers, divorced or broken up from a heterosexual relationship with a partner with whom they had one or more dependent children under 16 (totaling 17 children). Age ranged from mid-twenties to early fifties. The level of education ranged from vocational training to post-graduate university education. Nine fathers and four mothers were in full-time employment outside the home. Five mothers and one father were not employed but were under some form of work assessment scheme via the Norwegian Labor and Welfare Administration.

All parents had been to mediation at least once in the separation phase, and many had repeatedly sought both counseling and mediation at a family counseling office to help resolve issues of inter-parental disagreement. All parents reported having undergone assessment by child welfare services based on concern for an ongoing conflict. Twelve parents had been part of one or more court proceedings to settle disputes about custody or access. Five parents reported seeking psychotherapy or other professional counseling to deal with stress and trauma related to their current situation. Six of the children had been referred to hospital-based outpatient mental health services as part of their parents' and local professionals' responses to a concern for their well-being after their parents' separation. Most children had seen some form of first-tier consultation (e.g., health nurse, school social worker) either individually or as part of structured groups for children with parents in separate homes.

Parents were recruited through their participation in a multi-family group therapy program for parents and children who had been identified as part of a high-conflict divorce situation, ${ }^{3}$ which at the time of the study was run at two

\footnotetext{
${ }^{1}$ For one of the participating parents, their co-parenting ex-partner did not take part in the study.

${ }^{2}$ In the study that the paper draws on, a total of 20 parents were interviewed. Of these, 19 had experience with the child welfare services and were included in the data material used for this paper.

3 The groups were run in accordance with the 'No Kids in the Middle' model, which is a multi-family group framework for dialogical, systemic, and experiential therapeutic work with parents and children who live with long-lasting and high inter-parental conflict levels after
}

family counseling offices in the Agder region of Southern Norway. Parents were interviewed either before they participated in such a group (4), ${ }^{4}$ both before and after (7), or only four months after they had taken part (8). The program was run by professionals from family counseling centers and hospital-based outpatient child and youth mental health services. All parents had been referred to the program by caseworkers in the child welfare service, based on a concern for their children's situation in an ongoing conflict between the parents. As such, the multi-family group intervention program was part of an institutional sequence of parenting support services coordinated by the child welfare service. Contact with parents was made via the local therapists running the groups.

\section{Professionals}

Five child welfare caseworkers were interviewed. The caseworkers were not recruited based on their association with any particular case, and no attempt was made to link the experiences of particular parents and caseworkers. Instead, these interviews provided crucial supplementary information about the organization of professionals' work in cases involving high-conflict divorce. Caseworkers were recruited by contacting the director of a public child welfare service in the Norwegian Agder region.

In addition to interviews with parents and child welfare caseworkers, the study that this paper draws on included interviews with three judges and 12 family therapists. These were all recruited via direct contact. The interviews with therapists and judges were not used directly as part of the data material analyzed for the present paper. Still, they provided essential sources of knowledge about the institutional organization and local practices.

Interviews were audio-recorded and transcribed verbatim. Most parents (14) were interviewed in their own homes. Some (3) were interviewed at a family counseling office, and some (2) by telephone. ${ }^{5}$ Caseworkers were all interviewed at their workplaces. Interviews lasted from $30 \mathrm{~min}$ (by telephone) to two hours. All participants gave their informed

\section{Footnote 3 (continued)}

divorce (van Lawick \& Visser 2015). In the Agder region, this group program has been practiced since 2014 .

${ }^{4}$ Four parents interviewed before taking part in the multi-family group ended up not taking part in the group program but still agreed to participate in the study. Since the 'No Kids in the Middle' program itself is not the subject of study in this article, only the access point for contact, the interviews with these four parents were included in the material.

5 Two parents did not agree to be interviewed face-to-face or for the interview to be audio recorded. They consented to being interviewed via telephone and for the interviewer to take notes. 
signed consent to the use of the interview material for this research. The research project was approved by the Norwegian Center for Research Data (NSD, project nr. 57,881) and the ethical committee at the Faculty for Health and Sports Sciences, University of Agder.

\section{Data Production}

Interviews were conducted as semi-structured, open-ended conversations (DeVault \& McCoy, 2006). As is common to many versions of ethnographic interviewing (Hammersley \& Atkinson, 2007), in IE research, a material interview guide or fixed set of standard questions is seldom used (DeVault $\&$ McCoy, 2006). In individual interviews, questions were based partly on what was learned from previous interviews and partly on the researcher's accumulating knowledge of the social relations constituting the problematic under investigation. The parts of transcripts of interviews with parents used as data in this paper centered around each participant's history of encounters with welfare, legal and therapy professionals in the wake of separation or divorce. From transcripts of interviews with caseworkers from the child welfare service, data consisted of their accounts of experience from working with parents and children living with high levels of inter-parental conflict after divorce. In addition, I draw on texts that were either directly referenced in interviews or otherwise clearly implied (e.g., when a participant referred to "the legal framework," I searched for the legal texts appropriate to the situation referred to). I explored these texts to illuminate how the relations between parents and professionals in high-conflict divorce cases are "hooked up" (Smith, 2005) via trans-local ruling processes.

\section{Data Analysis}

\section{Memos}

After each interview, I wrote a memo containing my immediate impressions and reflections. I made notes of themes or issues that seemed to occur in several interviews to start tracing trans-local coordination patterns. Before each new interview, I consulted all existing memos to keep focused on developing analytic threads. I successively shared and discussed transcribed interviews with two of my research supervisors (a practicing mediator and family therapist and an associate professor in psychosocial health), widening the field of reflection and collectively generating ideas, concerns, and themes to be explored in coming interviews.

\section{Indexing}

In parallel with doing interviews and writing memos, I indexed accounts from the interview transcripts. As detailed by Rankin (2017), indexing is a strategy that helps keep analysis grounded in the materiality and particularities of actual accounts, as opposed to abstracting categories and themes from the data. Indexing helps the process of cross-reference across local activities, people, and settings. Guided by the research problematic, as the first step of the analysis, I scrutinized transcribed interviews with parents for accounts of meetings with professionals where some form of assessment was made, or where there was talk of a referral of the people in question as a 'case' between services (e.g., from child welfare to family counseling). These, I indexed according to which service was responsible for producing the assessment or institutional text that the individual event was related to. As a second step, I looked for each parent's accounts of experience from these encounters, how they responded to the events (i.e., if they appreciated or opposed what was done), and the knowledge they applied when responding. As the third step, I analyzed interviews with professionals, looking for their accounts of parallel work processes. For example, several parents found that professionals did not take their concerns regarding violence seriously. Thus, working with transcripts of interviews with child welfare caseworkers, I looked for accounts of work related to assessing and categorizing incoming concerns or referrals where there was mention of violence. Grouping different participants' accounts of the same type of event under the same index heading allowed for the assembling of interconnected accounts of experiences and knowledge from different subject positions. As the fourth step of the analysis, I searched within each index heading for references (explicit or by implication) to trans-local organizing texts, such as assessment forms or professional guidelines, and located them where possible.

Throughout the analysis, the emphasis was kept on people's doings and their expert knowledge about their doingswhat in IE terms is broadly referred to as 'work' (Smith, 2005). This focus on work sets IE apart from more conventional forms of qualitative inquiry that focus on informants' inner experience. It is participants' expert work knowledge that provides the entry point into the inquiry.

\section{Findings: Mapping the Institutional Circuit of Concern, Assessment, and Referral}

In this section, I seek to explicate how the institutional procedures governing child welfare caseworkers' engagement with families in high-conflict divorce situations gave shape to parents' experience, and how this work was related to, and contingent upon, the work of other professionals situated elsewhere. Alternating between parents' accounts of encounters with professionals and data from caseworkers' accounts of work related to the same kind of encounters, I 
show how parents' and caseworkers' doings were related to specific text-mediated ruling relations.

I begin by outlining the institutional circuit (Griffith \& Smith, 2014) of concern, assessment, and referral that is the study's focus. I then establish a standpoint in parents' experience inside this circuit to show how what is happening 'on the ground' is organized to happen as it does, more or less irrespective of the parents' knowledge and experience. I turn to data from interviews with child welfare caseworkers to explore how parents' experiential standpoint related to textually governed processes taking place beyond the immediately observable local setting. Focusing on one particular disjuncture (Smith, 1990a, 1990b) between the perspective of experience and the perspective of ruling, I then explore parents' experiential knowledge of how concerns about the other parent's capacity to provide proper care seemed to disappear or slip away once a situation was labeled as a high-conflict case. This, I connect to caseworkers' accounts of handling such concerns, showing how labeling a case as 'high-conflict' seemed to create barriers that complicated the articulation of other concerns. Finally, I show how engaging with this institutional circuit over time, for some parents, was associated with a sense of alienation and inertia.

\section{The Institutional Circuit}

Of the parents interviewed, all had been through a process of assessment by child welfare, resulting in a referral to a family counseling office for participation in a multi-family group therapy program (where they were re-assessed for suitability for the group). Some parents had initially contacted the child welfare service themselves due to concern for the other parents' ability to provide proper care. For others, the letter of concern had come from a mediator or therapist at a family counseling office or from a specialist psychologist working for the court (as part of a settlement agreement or following a main hearing).

In most cases where child welfare had been notified by a representative from either the court or a family counseling office, the particular multi-family group program from where parents were recruited to this study was explicitly mentioned in the letter of concern. According to the therapists, judges, and child welfare caseworkers interviewed, the locally negotiated set of procedures for referral to the multi-family group explicitly stated that a referral from child welfare was preferable. This was to establish the security of an active child welfare presence should the group therapy process not result in some form of meaningful improvement. This was in keeping with the governmental guideline describing the work of child welfare services vis-a-vis inter-parental conflict, which specifies that high-conflict divorce is considered legitimate grounds for opening a child welfare assessment (Barne-, likestillings- og inkluderingsdepartementet 2013).
Thus, a local institutional circuit existed, hooking the work of children, parents, therapists, child welfare caseworkers, judges, and others, onto each other. This was accomplished through a local formal policy agreement between services, anchored in professional guidelines (Barne-, likestillingsog inkluderingsdepartementet 2013) and law (Child Welfare Act 1992; Children Act, 1981). In the two next sections, I show how this ruling relation became visible in interviews with parents.

\section{Identifying a Standpoint in Parents' Experience}

During the two years since their separation, Robert ${ }^{6}$ and his ex-wife had repeatedly sought mediation at the local family counseling office. They were not in disagreement about custody or access for their two children (which was shared equally between the parents). However, they experienced enduring difficulties with agreeing on essential questions regarding priorities in their children's upbringing and resolving financial issues. At some point, a mediator at the family counseling office suggested they should join a multi-family therapy group for children and parents living with high levels of post-divorce conflict. When this was suggested, Robert thought that this group for "high-conflict families" would not be a good fit for them since he did not consider their conflict as "high," just stuck. Still, he and his ex-wife agreed to a referral to the therapy group. As a standard procedure in this process, the mediator at the family counseling office sent a letter of concern to the child welfare service articulating a worry that enduring conflict between the parents would threaten their children's psychosocial well-being. Robert described the meeting with a caseworker from the child welfare service, in conjunction with the caseworker making an assessment based on the letter of concern, as unsettling. In the assessment process, each parent was interviewed separately, and then the children were interviewed briefly. Based on the interviews, the caseworker wrote a report:

"There was a report. Which was ... she ended up setting the mother and me up against each other in that report. And that just made the conflict escalate. So, I called the caseworker and said that "this isn't right." And the mother called her too and said that the report isn't correct. It is entirely wrong. I told the caseworker that "you have to take it out." However, she had already locked the report, so there was nothing she could do."

This account shows a disjuncture between Robert's experience and knowledge about his life and the professionals' dealings with the same issues based on institutional

\footnotetext{
${ }^{6}$ Interview transcripts are anonymized. Parents have been given ficti-
} tious names. 
procedures that worked to objectify him, the mother, and their children as a case of a particular kind for which a specific set of procedures applied. In this process, a preordained set of local procedures for interaction between the family counseling office and the child welfare service provided direction for what the professionals should do and how. Investing in these relations of ruling (in this case to be found in the letter of concern, the standardized assessment protocol, and the letter of referral to the group), collectively working as operationalizations of the government guideline (Barne-, likestillings- og inkluderingsdepartementet 2013), seems to have made the actual experiences and knowledge of the people under assessment seem less relevant. Nevertheless, the parents invested in this; they agreed to the referral and accepted the offer of therapy (even though the offer was based on the report they objected to).

Other parents described a sense of relief and comfort that there existed a set of guidelines and procedures for how professionals were to deal with parents in enduring post-divorce concerns. Anna said that she had felt relieved when her general practitioner had told her that she was "not supposed to struggle with this alone," and referred her to the child welfare service. Anna said that before this, she had felt very alone with the dilemmas associated with co-parenting with a father whose lifestyle she described as "criminal" at the time. Learning to formulate her worries as concerns about inter-parental conflict let her access the help that she felt she needed more readily: "it was much easier to go to child welfare and ask for help when you knew what you were supposed to ask for help with." After the latest round of assessment, she said that the caseworkers in child welfare "really wanted us to accept a referral" to the multi-family group therapy program at the family counseling office. Although she described the relationship between the father and herself as good at this time, she trusted that the professionals knew what would be best for them. Hence, she was happy to accommodate their suggestions. However, this trust was not based on an interpersonal relationship with a caseworker developing gradually over time, as there would be new people in charge of their case "every time." Although this progression along an institutional sequence of actions was not grounded in her experience in an obvious way, I interpret her account as communicating a sense of being cared for and acknowledged.

Emma, too, had experienced child welfare services as a source of support during the time after the divorce. Her family had initially come into contact with child welfare because her son showed behavioral problems in school:

"And then, luckily, the caseworker understood that there was a conflict there, too, affecting the children, in addition to the challenges that our son had. And then she suggested we attend a conflict group. The father was skeptical (...), but I accepted the offer right away. I ... I accept everything that might be of help. Because I have tried so many things, I think. The health nurse, family counseling, but nothing has really been of help thus far."

Emma and Anna placed their trust in the welfare system and expressed gratitude that their situation was defined as a high-conflict case since this opened the possibility for being referred to therapeutic services that they hoped would contribute to making life better.

Some parents said that agreeing to professionals' suggestions for further referrals was all part of a more comprehensive give-and-take negotiation between the parents and various bodies of government. Some parents had responded to the suggestion made by professionals to refer both parents to a multi-family group therapy program by demanding that the other parent be referred individually to a separate service (e.g., psychiatric assessment, a parenting group focusing on parent-child attachment, or an anger management program). Others described such referrals as something they felt they had to agree to because of some prior accommodation (e.g., previously having experienced that one's concerns were taken seriously by child welfare), or in the hope that it would bring about a specific governmental response in the future (e.g., hoping that exhibiting a positive attitude by accepting a referral at this point might prove critical in a future court proceeding). Ole said that his reason for accepting a referral to the particular multi-family group therapy program where the parents for this study were interviewed, was simply that the child welfare service had recommended it. Since he was the one who had initially contacted this service for help, he felt obliged to accept. "Otherwise, asking for help would make no sense. Thus, I feel somewhat pressured, out of respect, because I have been happy with the child welfare service. ... Nevertheless, I don't believe that anything good will come of it."

Although diverse, these parents' experiences can be understood as originating within a generalized sequence of action (Smith, 2005), or institutional circuit, grounded in knowledge and decisions originating outside of the local context of experience. The parents' participation in these discursive practices brought them into connection with the trans-local ruling relations of text-based forms of knowledge. To understand some of these complex translocal processes informing parents' experiential standpoint, I now turn to material from interviews with child welfare caseworkers to explore how this related to textually governed processes taking place beyond the immediately observable local setting. 


\section{The Work of Child Welfare Caseworkers}

Because of the legal framework regulating the Norwegian child welfare service (Child Welfare Act 1992), other services or institutions cannot request a specific structured response from this service in a particular case without presenting the request as a letter of concern. Several of the caseworkers interviewed explained that receiving a letter of concern about inter-parental conflict, suggesting a referral to a particular intervention outside of the child welfare service itself, would place them in a difficult situation. On the one hand, in each particular case, this meant that a decision about the suitability of the intervention in question had been made elsewhere and that what was essentially called for was the bureaucratic continuation of this decision. On the other hand, as specified in the "Routine Manual for Child Welfare Services" (Barne- og likestillingsdepartementet 2006), the child welfare service cannot initiate a referral to a particular program or any other parenting support measure without first making an independent assessment of the conditions of care that supports (or not) the likelihood of a causal relationship between the measure proposed and the amelioration of the particular issues of concern. Furthermore, unless by the decision of the County Social Welfare Board (Child Welfare Act 1992, §4-4), any family support initiative is conditioned on both children's and parents' voluntary participation.

Referring in particular to instances where the child welfare service would receive such a letter of concern in the wake of a court proceeding, where a decision to participate in a particular therapeutic program was part of either a settlement or a court ruling, one caseworker explained:

"We often feel ...restrained by what the court asks for. You see, it doesn't fit the system. [...] According to the Child Welfare Act, we can't just pass it on to [the team working with] family support. We have to investigate. And what are we to investigate, then? We can choose to simply let the assessment consist of the court ruling, one conversation with each of the parents and the children, and then proceed. However, perhaps we should be much more exact on the need to speak thoroughly with the children, to make sure they know what has been decided. [...] But that means initiating a full investigation, which involves a lot of work before the case can move on to family support."

Similarly, from the standpoint of child welfare caseworkers, as a standardized procedure, it seemed overly cumbersome when a therapist at the family counseling office would send a letter of concern requesting that the child welfare service refer a particular family back to them for participation in a program that the family counseling office was already administering. "If I was a parent in that situation, at the family counseling office," one caseworker said, "I would have thought "why do I have to go through child welfare? I am already here! I accept the offer to attend the program, but I don't see why you have to report me to child welfare.' That's how I would think."

The request to make a referral formulated in the letter of concern, combined with the need to make an assessment that would meet the formal demands of child welfare legislation, including the condition that participation in a family support intervention initiated by child welfare needs to be voluntary on the part of parents, left caseworkers with a sense of having very little room for maneuvering in these particular cases. Often, one caseworker said, they saw that their work in the assessment process was experienced as stressful by parents and that this would often make the conflict escalate. In this situation, several caseworkers said that spending too much time with one parent one-on-one (as opposed to only speaking to parents together) involved a risk of the caseworker either subjectively choosing a side in the conflict, or else at least providing the other parent with a reason for suspecting them of partiality. While the caseworkers interviewed all had limited experience with referring families to specific programs outside of their own service, all had ample experience with "losing" cases due to accusations from one parent that a child welfare assessment was not made from an objective stance. As such, the institutional circuit of concern, assessment, and referral between the institutions involved a sequence of institutional boundaries that worked to complicate the actualization of other concerns than those directed at the conflict as a phenomenon in itself, from personal disquiet into some form of conversational reality.

In the next section, I focus on one concern that stood out when analyzing interviews with parents. This particular concern had to do with the experience that knowledge of violence or parents' drug abuse seemed to disappear or slip away once a situation was labeled as a high-conflict case.

\section{Silencing Concerns}

Among the parents who said that violence was an important issue of concern for them, a shared experience was that their talk of violence had been categorized as false allegations or otherwise merely had not registered with professionals.

Accounting for his way into the multi-family group program in conjunction with which he was interviewed, Ole described a complex parental custody dispute that had evolved over several years. His story involved three separate rounds of court litigation, activating contact with several community health and welfare services and him suspecting the other parent of using illicit drugs and accusing her of violence before the break-up. In his experience, this situation was interpreted by professionals in child welfare and family counseling as a "traditional quarrel." By this, he referred to the situation being described as one where each parent 
wrongly accused the other of poor parenting, jointly failing to shield the child from hearing these accusations. Based on this, he said, the situation was defined as "high-conflict" and referred by the child welfare service to the family counseling office for assessment for group therapy participation. There, they were met as two parents equally contributing to and thus equally responsible for the conflict. In his words, this view was communicated via statements like "you have some things to tidy up between the two of you," "you need to take hold of this situation," and "you can't continue like this." He said that he could understand the logic behind this perspective and that it would have been much preferable if what they needed to do was to sort out practical issues and agree to treat each other with a higher level of decency:

"And not the other stuff with lies, violence, drugs, and all that. And then the child welfare service says, "we recommend the family counseling office." But that is like ... it is either that or promoting a care order. They really don't have much more they can say. Still, I have decided to go along with it because I was happy with the therapists we met. They seemed very professional and objective and balanced."

Although the definition of their situation as one where both parents were mutually responsible and equally contributing did not fit with his own experience, he still stepped into and chose to invest in the generalized high-conflict divorce case's social relations.

Randi, a mother interviewed four months after she had participated in the multi-family group, explained that the group, for her, presently marked the endpoint of a long series of engagements with professionals in what she described as her work for "saving" her children. This had been her main focus ever since the children told her that their father was sometimes physically abusive towards them when they stayed with him (which was every other week). However, the father denied the occurrence of violence, turning the situation into one of "word against word." In her experience, the lack of tangible proof of violence directed the professionals' attention away from the contents of her concern, turning it instead towards the heated and insistent manner in which the concerns were communicated. Her previous attempts at seeking help included repeated mediation, therapy from mental health services for both herself and her children, and assessment and subsequent parenting advice and support from child welfare services:

"I didn't feel that mediation or any of the other stuff helped me. It sounds so grand: "we listen to the children." The youngest one came to mediation and said, "I want to stay with my mother" - no one did anything. "It is the conflict; it is the conflict," they say. OK. I haven't had a quarrel with that man for a long time.
Still, he throws my kid on the floor. So, don't come dragging with the conflict."

In this mother's experience, her talk of the father's violence was interpreted as a false allegation. For the various professionals meeting them, this seems to have made the dynamics of the relationship between her and her ex-husband fit with a "typical" high-conflict divorce pattern, thus appointing high-conflict as an objectified phenomenon to be the problem, and not the actual material, localized doings of people. Within this social organization, priority was given to particular conflict behaviors at the expense of the issues that these behaviors, as understood by the parent as acting subject, were experienced as responses to.

\section{The Work of Child Welfare Caseworkers}

In interviews with child welfare caseworkers, several participants endorsed the same dilemmas that parents brought up, particularly the possibility of misjudging information about violence or drug use as unfounded accusations. "But because the case is [defined as] high-conflict, we don't go into it," one caseworker said. She described the dilemma as one between firing up the conflict if they were to act on the information versus overseeing instances of actual abuse if they did not. Describing how a typical high-conflict case would enter the child welfare system if the letter of concern was sent by one of the parents themselves, one caseworker explained that:

Caseworker: "In those cases, ... often, the letter of concern will mention issues of mental health or drug use. Claims about the other parent using drugs. In some cases, the issues will be more about the other parent not doing things in the appropriate way ..."

Interviewer: "Like following up on homework, perhaps..."

Caseworker: "... or that the child always wears dirty clothes after being with the other parent, a lot of details, which of course might prove important, but where they... well, it is... these are cases that can weigh heavily on you. Because [parents] get so caught up in the details and not ... [...], and I think that is the point when we might begin to understand it as an instance of a lack of insight, or as a lack of ability to see oneself as contributing to the situation."

In this account, a disjuncture can be hypothesized as the event where the content of parents' expressed concerns become subordinated, while the general rhetorical form in which the concerns are communicated comes to take center stage. This shift makes what occurs actionable as a highconflict case (as opposed to a case where one parent is suspected of failing to provide proper care). 
When child welfare caseworkers would refer families to particular family therapy interventions, a de-escalation of conflict was not considered the sole possibly valuable outcome of the process. An unfavorable outcome, meaning that the therapeutic efforts did not lead to the desired change, could work to build a child welfare case towards a possible care order or encourage one parent to initiate a custody case in court. Describing the Child Welfare Act as strict and rigid, and the power to place children in care as a latent threat frightening many parents from cooperating with the child welfare services, one caseworker described that the family counseling service, in his understanding, was a more welcoming and service-minded institution. If a caseworker would refer a family to the family counseling service and then later get a letter of concern in return, describing one or both parents as refusing to cooperate with the family therapists, this would contribute to building the case about neglect as a result of conflict between the parents. "When you get it served, when people wish you nothing but well and just want to help you, and you refuse-who are you then? How do you think?" one caseworker said.

The above examples illustrate how a specific textualized ruling discourse about post-divorce parenting and interparental disagreements worked to position both parents and professionals. Engaging with each other through textually organized sequences of interaction, they entered into and actively participated in the ruling practices contained in the texts. Within the specific institutional circuit explored here, describing an interpersonal relational dynamic as 'high-conflict' would catch the local moment into a set of discursive relations organized around an understanding of conflict as a malfunctioning mode of parenting. This created barriers complicating the articulation of other concerns, like worries about ongoing violence and drug abuse.

\section{Paranoid Parenting}

Several parents articulated a sense of being under constant surveillance due to being identified as part of a high-conflict divorce case. Some used the word "paranoia" to describe what living within this situation over time was doing to them. After eighteen months of contact with child welfare as a consequence of concern for the effects of conflict on his children, Martin explained that "for the last year-and-a-half, my whole life, and my children's lives, have been put under a magnifying glass. [...] Poof, everything is affected." Ivar described his experience with being under assessment by child welfare as "being evaluated up and down [...] without ever getting any feedback, they just evaluate ... you get stuck in an enduring evaluation where you just sit around feeling like the worst father in the world, like, what am I doing wrong since they never back off, in a way?" Maria explained that:
"Everyone who has been in contact with child welfare or been through a custody trial says the same thing. Suddenly you think ... when your child does whatever: how does this look from the outside? What will my child say about this when someone asks her about it? Most families never have to consider such things. And then I think: that is freedom."

Linda had spent the two years since separation in dialogues with child mental health services, school psychology services, health nurses, and her own and her children's general practitioner before taking part in the multi-family group program in relation to which she was interviewed. She explained that the sense of not being taken seriously or understood by professionals, particularly in the child welfare service, had led her to keep documentation of almost everything that happened in her and her children's lives. "I just put it all in binders. Everything ... I can get. But still, that makes ... a lot of hours that I could have spent otherwise." She believed that it would have been much better for her children to have spent her energy on them instead of becoming exhausted over documenting their misery. "And on ... public services that haven't really proven to be useful ... or helpful ... for the children."

\section{Discussion}

Using the concepts and mode of inquiry of institutional ethnography, I have sought to explore a small segment of the social organization of high-conflict divorce as it came into view when seen from the standpoint of Norwegian parents engaging with services catering to post-divorce concerns. The purpose of the institutional procedures studied was to help identify families struggling with high-conflict divorce and establish a reasonable and professionally sound offer of family therapy services. Focusing on disjunctures between subjective experience and institutional knowledge, the analysis has brought into view how parents' and professionals' actions are shaped by engaging with the social organization built into the procedures constituting this particular institutional circuit. Sometimes, this invites paths of action that come into conflict with what the individual agents themselves know and care for.

This particular study should not be interpreted as a critique of the work that professionals do. Nor does it provide an argument against state involvement in family affairs. Instead, it points to the intricate entanglement of individual experience and organizational order that characterizes the social organization of post-divorce conflict. While some of the parents interviewed for the present study valued the services provided by professionals, many said that engaging with institutional services had not contributed to the 
resolution of conflict or the betterment of life. In some cases, it had led parents to gradually adopt a third-person perspective of ruling vis-à-vis themselves, documenting their own and their children's misfortune in lack of any viable alternatives that would count as an action within the institutional order.

In a systematic literature review of qualitative research on parents' experience of high-conflict co-parenting relationships after divorce, Francia et al. (2019) summarize that concerns over differing parenting styles, or the other parent's ability to care for the child adequately, were among the most common ingredients in parents' descriptions of conflicts. The experiences and expressed motives of the parents interviewed for the present study mostly fit these descriptions. The present findings further highlight the risk of losing from sight the concerns that bring people to seek welfare or therapeutic services in the first place. Treloar $(2018,2019)$, interviewing Canadian adults who had experienced a highconflict divorce, found that while many of her participants saw themselves as having done what was within their power to make the best of the situation for themselves and their children, they still experienced being stereotyped, judged, boxed in and labeled by professionals. The present study suggests that approaching such experiences in terms of the ruling relations that hook parents' concerns onto legal, welfare, and therapy services can broaden our understanding of how this comes to happen. Moving along institutionalized sequences of encounters where institutional texts get produced, personal lived experience is abstracted and translated to be intelligible within a professional discourse, sanctioned in official guidelines and in legal and scientific authority. This works to categorize people's situations and concerns in ways that make them institutionally actionable as high-conflict cases. However, the subsequent institutional action can sometimes be experienced as irrelevant or even alienating.

\section{From Family Systems to Societal Entanglement}

The particular model for multi-family therapy in which all families in the present study either were about to participate or had already participated (the 'No Kids in the Middle' program, see No Kids in the Middle 2020; van Lawick \& Visser, 2015), encourages therapists to consider inter-parental conflict as a systemic phenomenon extending beyond the children-parents nucleus. Therapeutic work adhering to this model includes one or more network meetings where members of families' private networks, like grandparents, siblings, or new partners-and sometimes the children's teachers or parents' colleagues, can be invited. The rationale for this is that members of the network are often actively involved in conflict by taking sides, thus contributing to a conflict dynamic rather than de-escalation or resolution (van Lawick \& Visser, 2015).
The present study supports an even more comprehensive understanding of the dynamics of inter-parental conflicts. It points to how the trans-local, ruling relations of policy documents, professional guidelines, and local procedures sometimes work to raise institutional boundaries that keep parents and professionals alike from relating to issues of dispute and concern as anything other than a reciprocal high-conflict divorce pattern. Johnson, Roseby, and Kuehnle (2009) argue that professionals' rhetoric sometimes promotes the growth of the same phenomena that it addresses in the hope of resolution or prevention. The present study shows how this sometimes happens in situated interchanges between parents and professionals. I suggest that this can be understood as subjective responses to the objectified, or ruling, social relations brought into being as trans-local ruling relations are repeatedly activated in local settings where professionals follow procedure. This raises the question of what fuels the pervasive distrust, poor communication, disregard, contempt, polarization, and imperviousness to rational positions or arguments (Kelly, 2003) that professionals sometimes observe in parents in high-conflict divorce cases (McIntosh, 2003).

For practitioners in this field, this suggests that it is crucial to consider 'high-conflict divorce' not only as a useful concept referring to a particular type of interpersonal dynamics; it can also be understood as a regulatory frame (Smith, 2005), organizing the trans-local social relations within (or against) which it is locally realized and experienced. As professionals, one's involvement - why to engage, how to approach, when, where, and how to intervene (or abstain from it)-is already part of this institutional complex. Thus, it is sometimes difficult to distinguish helpful intervention from continuation or even reinforcement of the processes that work to uphold and fuel conflicts.

\section{Implications for Practice}

McIntosh (2003) urges that research documenting the negative consequences of post-divorce conflict for children should warn professionals that "continuing to practice in ways that do not actively create a child focus can no longer be regarded as good practice in primary dispute resolution." The present study presents a complex portrait of what goes on when parents and professionals engage with each other to realize such an agenda. As professionals knowingly and competently produce the practices that are called for and make sense within their respective institutional settings (Rankin, 2015), the subjective experience and knowledge of the individual people that jointly constitute each highconflict divorce case risk being overlooked. Sometimes, this seems to lead to a sense of alienation and lack of agency on the part of parents that it is hard to imagine as a positive outcome for anyone-let alone the children. Nevertheless, the 
trans-local ruling relations that these practices are informed by, in the shape of practice guidelines, policies, and legal regulations, are all explicitly prepared with the "best interests of the child" as an ultimate concern.

This study highlights the importance of seeing the actions of the people involved-family members as well as the professionals in adjoining institutional services that families come into contact with - not only as expressive of fixed positions, intra-personal characteristics, or inter-personal patterns of communication. We can also understand them as responses bounded by trans-local ruling relations that organize the very situations in which help is sought and offered. Awareness of this might make visible how engaging with the ruling relations that organize these exchanges sometimes erect institutional boundaries that make any other response than going along seem unattainable. This invites a reflective kind of practice where practitioners should be mindful of and engage parents and children in dialogues about their own and each other's positions within the institutional circuitry.

\section{Coda-Local Action}

Since its beginning (in September 2017), part of the motivation behind the research project that this paper is a part of has been to contribute to the conditions for such a local reflective practice. To this end, as a researcher, I took part in a joint collaborative forum twice a year. There, therapists working with the particular multi-family intervention program from which all parents participating in this study were recruited (the 'No Kids in the Middle' model (van Lawick \& Visser, 2015)) in the Agder region of Norway, together with their administrative leaders, met with representatives from child welfare services and the district courts to share experiences and concerns and to discuss further joint efforts to improve institutional services for families in high-conflict divorce situations. At these meetings, information about the research process and the emerging findings was provided and discussed with the participating professionals. Four therapists from one of the family counseling offices coordinating the multi-family group practice in Agder read the first draft of the manuscript for this paper and took part in a discussion of the findings. They responded that the concerns raised in the manuscript resonated with their own experiences and with concerns they had felt but not always found productive ways for articulating. As a result of these discussions, it was decided to initiate a monthly forum for dialogue around institutional services to parents and children struggling with enduring conflicts and other concerns after separation or divorce. There, therapists from this family counseling office and the citizens, organizations, and public services in the communities served by it will be invited to share experiences, thoughts, and ideas concerning what good institutional services in this particular field should involve.
Acknowledgments The author thanks Tore Dag Bøe, Ella Kopperud, Rolf Sundet and Gert Biesta, who act as supervisors for the Ph.D. study that the present paper is part of. Thank you also for the highly constructive feedback and suggestions from the three anonymous reviewers.

Funding Open access funding provided by University of Agder.. The research is part of a study funded by the Norwegian Research Council (public sector Ph.D., project no: 272378), Bufetat region south/The Family Counseling Office in Arendal, Norway, and South Norway Hospital, Department of Child and Youth Mental Health.

Data Availability The interview transcripts for this study will not be made publicly available. While the transcripts have been de-identified, the content is still personal and cannot be made fully anonymous without changing the content. If made publicly available, participants would therefore be able to recognize themselves, as well as possibly recognizing each other.

\section{Declarations}

Conflict of interest The author reports no conflict of interest.

Open Access This article is licensed under a Creative Commons Attribution 4.0 International License, which permits use, sharing, adaptation, distribution and reproduction in any medium or format, as long as you give appropriate credit to the original author(s) and the source, provide a link to the Creative Commons licence, and indicate if changes were made. The images or other third party material in this article are included in the article's Creative Commons licence, unless indicated otherwise in a credit line to the material. If material is not included in the article's Creative Commons licence and your intended use is not permitted by statutory regulation or exceeds the permitted use, you will need to obtain permission directly from the copyright holder. To view a copy of this licence, visit http://creativecommons.org/licenses/by/4.0/.

\section{References}

Amato, P. R. (2000). The Consequences of Divorce for Adults and Children. Journal of Marriage and Family, 62(4), 1269-1287. https://doi.org/10.1111/j.1741-3737.2000.01269.x

Amato, P. R., \& Keith, B. (1991). Parental Divorce and the Well-Being of Children: a Meta-Analysis. Psychological Bulletin. https://doi. org/10.1037/0033-2909.110.1.26

Anderson, S. R., Anderson, S. A., Palmer, K. L., Mutchler, M. S. \& Baker, L. K. (2010). Defining High Conflict. The American Journal of Family Therapy, 39(1), 11-27. https://doi.org/10.1080/ 01926187.2010.530194

Anderson, S. R., Sumner, B. W., Parady, A., Whiting, J., \& Tabling, R. (2019). A Task Analysis of Client Re-engagement: Therapeutic De-escalation of High-Conflict Coparents. Family Process (early view). https://doi.org/10.1111/famp.12511

Barne,- likestillings- og inkluderingsdepartementet (2013). Forholdet mellom barnevernloven og barneloven - Barneverntjenestens rolle der foreldrenes konflikter går ut over barnets omsorgssituasjon. https://www.regjeringen.no/no/dokumenter/ny-veileder-om-forho ldet-mellom-barnever/id731863.

Barne,- og likestillingsdepartementet (2006). Rutinehåndbok for barneverntjenesten i kommunene. https://www.regjeringen.no/globa lassets/upload/kilde/bld/bro/2006/0007/ddd/pdfv/284439-q-1101. pdf. 
Barne- og familiedepartementet (2006). Forskrift om mekling etter ekteskapsloven og barneloven (FOR-2006-12-18-1478). https:// lovdata.no/dokument/SF/forskrift/2006-12-18-1478.

Bergman, A. S., \& Rejmer, A. (2017). Parents in Child Custody Disputes: Why Are They Disputing? Journal of Child Custody., 14(23), 134-150. https://doi.org/10.1080/15379418.2017.136532

Birnbaum, R., \& Bala, N. (2010). Toward the Differentiation of HighConflict Families: An Analysis of Social Science Research and Canadian Case Law. Family Court Review, 48(3), 403-416. https://doi.org/10.1111/j.1744-1617.2010.01319.x

Child Welfare Act (1992). Lov om barneverntjenester (LOV-199207-17-100). https://lovdata.no/dokument/NL/lov/1992-07-17100 ? $\mathrm{q}=$ barnevernloven

Children Act (1981). Lov om Barn og Foreldre (LOV-1981-04-08-7). https://lovdata.no/dokument/NL/lov/1981-04-08-7?q=barneloven.

DeBoard-Lucas, R. L., Fosco, G. M., Raynor, S. R., \& Grych, J. H. (2010). Interparental Conflict in Context: Exploring Relations Between Parenting Processes and Children's Conflict Appraisals. Journal of Clinical Child \& Adolescent Psychology, 39, 163-175.

DeVault, M. L. \& McCoy, L. (2006). Institutional Ethnography: Using Interviews to Investigate Ruling Relations. In Smtih, D. (ed.). Institutional Ethnography as Practice (pp. 15-44). Rowman \& Littlefield.

Domstoladministrasjonen (2019). Nasjonal veileder for behandling av foreldretvister. Accessed from https://www.domstol.no/conte ntassets/2af0ab33bb6146ffa161a41154de85f7/nasjonal-veilederfor-foreldretvister-2019-1.pdf.

Emery, R. (1999). Marriage, divorce, and children's adjustment. (2nd ed.). Sage.

Fincham, F. D., Grych, J. H., \& Osborne, L. N. (1994). Does Marital Conflict Cause Child Maladjustment? Directions and Challenges for Longitudinal Research. Journal of Family Psychology, 8, 128-140. https://doi.org/10.1037/0893-3200.8.2.128

Francia, L., Millear, P., \& Sharman, R. (2019). Mothers and Fathers' Experiences of High Conflict Past Two Years Post Separation: A Systematic Review of the Qualitative Literature. Journal of Child Custody, 16, 170-196. https://doi.org/10.1080/15379418. 2019.1617821

Griffith, A. \& Smith, D. E. (2014). Under new public management: Institutional ethnographies of changing front-line work. University of Toronto Press.

Grych, J. H. (2005). Interparental Conflict as a Risk Factor for Child Maladjustment: Implications for the Development of Prevention Programs. Family Court Review, 43, 97-108. https://doi.org/10. 1111/j.1744-1617.2005.00010.x

Haddad, L., Phillips, K., \& Bone, J. (2016). High-Conflict Divorce: A Review of the Literature. American Journal of Family Law, 29, 243-258.

Hammersley, M., \& Atkinson, P. (2007). Ethnography: Principles in Practice (3rd ed.). Routledge.

Helland, M. S., \& Borren, I. (2015). Foreldrekonflikt: Identifisering av Konfliktnivåer, Sentrale Kjennetegn og Risikofaktorer hos Høykonfliktpar. Folkehelseinstituttet. Rapport, 2015, 03.

Hetherington, E. M. (2002). For Better or for Worse: Divorce Reconsidered. Norton.

Hussey, I. (2012). "Political Activist as Ethnographer" Revisited. Canadian Journal of Sociology. https://doi.org/https://doi.org/10. 29173/cjs10214

Johnston, J., Roseby, V., \& Kuehnle, K. (2009). In the Name of the Child - A Developmental Approach to Understanding and Helping Children of Conflicted and Violent Divorce. Springer.

Kearney, G. P., Corman, M. K., Gormley, G. J., Hart, N. D., Johnston, J. L., \& Smith, D. E. (2018). Institutional ethnography: a sociology of discovery - in conversation with Dorothy Smith. Social Theory \& Health, 16(3), 292-306. https://doi.org/10.1057/ s41285-018-0077-2
Kearney, G. P., Corman, M. K., Hart, N. D., Johnston, J. L., \& Gormley, G. J. (2019). Why institutional ethnography? Why now? Institutional ethnography in health professions education. Perspectives on Medical Education, 8(1), 17-24. https://doi.org/10. 1007/s40037-019-0499-0

Kelly, J. B. (2003). Parents with Enduring Child Disputes: Multiple Pathways to Enduring Disputes. Journal of Family Studies, 9, 37-50. https://doi.org/10.5172/jfs.9.1.37

Koch; K. . (2008). Evaluering av Saksbehandlingsreglene for Domstolene i Barneloven - Saker om Foreldreansvar. Fast bosted og Samvær.

Lansford, J. A. (2009). Parental Divorce and Children's Adjustment. Perspectives on Psychological Science, 4(2), 140-152. https://doi. org/10.1111/j.1745-6924.2009.01114.x

Mahrer, N. E., O'Hara, K. L., Sandler, I. N., \& Wolchik, S. A. (2018). Does Shared Parenting Help or Hurt Children in High-Conflict Divorced Families? Journal of Divorce \& Remarriage, 59, 324 347. https://doi.org/10.1080/10502556.2018.1454200

Marriage Act (1991). Lov om Ekteskap. (LOV-1991-07-04-47). https://lovdata.no/dokument/NL/lov/1991-07-04-47.

McIntosh, J. (2003). Enduring Conflict in Parental Separation: Pathways of Impact on Child Development. Journal of Family Studies, 9, 63-80. https://doi.org/10.5172/jfs.9.1.63

No Kids in the Middle (2020). No Kids in the Middle. http://kinderenui tdeknel.nl/index?lang=en.

Ottosen, M. H. (2006). In the Name of the Father, the Child and the Holy Genes: Constructions of 'The Child's Best Interest' in Legal Disputes over Contact. Acta Sociologica, 49(1), 29-46. https://doi. org/10.1177/0001699306061898

Parkinson, P. (2011). Family Law and the Indissolubility of Parenthood. Cambridge University Press.

Rankin, J. (2015). The rhetoric of patient and family centred care: An institutional ethnography into what actually happens. Journal of Advanced Nursing, 71(3), 526-534. https://doi.org/10.1111/jan. 12575

Rankin, J. (2017). Conducting Analysis in Institutional Ethnography: Guidance and Cautions. International Journal of Qualitative Methods. https://doi.org/10.1177/1609406917734472

Smith, D. E. (1987). The Everyday World as Problematic: A Feminist Sociology. University of Toronto Press and Northeastern Press.

Smith, D. E. (1990a). Texts. Exploring the relations of ruling. Routledge.

Smith, D. E. (1999). Writing the Social: Theory, Critique. University of Toronto Press.

Smith, D. E. (2005): Institutional Ethnography: A Sociology for People. Alta Mira Press.

Smith, D. E. (2006). Introduction. In Smith, D. E. (ed.) Institutional Ethnography as Practice (pp. 1-11). Rowman \& Littlefield.

Smith, G. W. (1990b). Political Activist as Ethnographer. Social Problems, 37(4), 629-648. https://doi.org/10.1525/sp.1990.37.4.03a00 140

Statistics Norway (2020). Familier og husholdninger. https://www.ssb. no/statbank/table/06204.

Treloar, R. (2018). High-Conflict Divorce Involving Children: Parents' Meaning-Making and Agency. Journal of Social Welfare and Family Law, 40, 340-361. https://doi.org/10.1080/09649069. 2018.1493652

Treloar, R. (2019). Parents making meaning of high-conflict divorce. Australian and New Zealand Journal of Family Therapy, 40, 85-97. https://doi.org/10.1002/anzf.1347

Van Lawick, J., \& Visser, M. (2015). No kids in the middle: dialogical and creative work with parents and children in the context of high conflict divorces. Australian and New Zealand Journal of Family Therapy, 36(1), 33-50. https://doi.org/10.1002/anzf.1091 
Vimblemo, T.E., Tobra, M., Knutsen V.S., Olsen L.O., Gleinsvik A. \& Bush R., (2016) Domstolsbehandlingen av foreldretvister. Report by Oxford Research in collaboration with Proba samfunnsanalyse.

Visser, M., Finkenauer, C., Schoemaker, K., Kluwer, E., van der Rijken, R., van Lawick, J., Bom, H., \& Lamers-Winkelman, F. (2017). I'll never forgive you: high conflict divorce, social network, and co-parenting conflicts. Journal of Child and Family Studies, 26, 3055-3066. https://doi.org/10.1007/s10826-017-0821-6
Wiik, K. A., Kitterød, R. H., Lyngstad, J. \& Lidén, H. (2015). Samarbeid mellom foreldre som bor hver for seg. Statistisk Sentralbyrå.

Publisher's Note Springer Nature remains neutral with regard to jurisdictional claims in published maps and institutional affiliations. 